\title{
Vanadium derivatives act as growth factor- mimetic compounds upon differentiation and proliferation of osteoblast-like UMR106 cells
}

\author{
Ana M. Cortizo ${ }^{1}$ and Susana B. Etcheverry ${ }^{1,2}$ \\ 'Cátedra de Bioquimica Patológica, Facultad de Ciencias Exactas; ${ }^{2}$ Programa QUINOR, Facultad de Ciencias Exactas, \\ Universidad Nacional de La Plata, 47 y 115 (1900) La Plata, Argentina
}

Received 14 May 1994; accepted 21 November 1994

\begin{abstract}
The effect of different vanadium compounds on proliferation and differentiation was examined in osteoblast-like UMR106 cells. Vanadate increased the cell growth in a biphasic manner, the higher doses inhibiting cell progression. Vanadyl stimulated cell proliferation in a dose-responsive manner. Similar to vanadate, pervanadate increased osteoblast-like cell proliferation in a biphasic manner but no inhibition of growth was observed. Vanadyl and pervanadate were stronger stimulators of cell growth than vanadate. Only vanadate was able to regulate the cell differentiation as measured by cell alkaline phosphatase activity. These results suggest that vanadium derivatives behave like growth factors on osteoblast-like cells and are potential pharmacological tools in the control of cell growth. (Mol Cell Biochem 145: 97-102, 1995)
\end{abstract}

Key words: vanadium compounds, osteoblast-like cells, proliferation, differentiation, bone development, growth factors

\section{Introduction}

Osteoblasts are important cells involved in bone formation. Their activity is regulated by several systemic hormones (growth hormone, GH; insulin; glucocorticoids; parathyroid hormone, PTH; vitamin D) and local factors like transforming growth factor (TGF), fibroblast growth factor (FGF), insulin-like growth factors (IGFs), platelet-derived growth factor (PDGF) [1-3]. Systemic hormones can act directly on the bone or by inducing the secretion of cytokines and growth factors [4]. It has been found that human bone cells in culture produce a number of growth factors, many of which are known to be stored in human bone, including IGF-I, IGF-II, TGF- $\beta$ and PDGF [5]. The hormonal action is mediated by cell surface specific receptors identified in osteoblasts in culture [6-8]. On the other hand, several ions ( $\mathrm{Ca}, \mathrm{Zn}, \mathrm{P}, \mathrm{Mn}$, $\mathrm{Cu}, \mathrm{V})$ also modulate the activity of the bone cells $[9,10]$.

Vanadium is an essential nutritional element and its deficiency causes growth inhibition and skeletal deformation in animals [10]. Vanadate shows significant biological effects on bone development $[11,12]$; it also acts like an insulinmimetic factor [13]. Recently, different vanadium compounds, such as pervanadates, have been shown to stimulate the intracellular levels of phosphoproteins [14-16]. Although the intimate molecular mechanism of their action is still unknown, it is probably mediated by the inhibition of protein phosphotyrosyl-phosphatases (PTPases) $[14,17]$. We have recently shown that vanadate, vanadyl, peroxo- and hydroperoxovanadium compounds selectively inhibit a bone soluble alkaline phosphatase, partially characterized as a PTPase [18].

The aim of the present study was to obtain a deeper insight into the effects of vanadium derivatives on the proliferation and differentiation of osteoblast-like UMR 106 cells in culture. UMR 106 cells are clonal osteosarcoma cells that have preserved many different properties of osteoblasts, including cAMP responsiveness to $\mathrm{PTH}$, high alkaline phosphatase and synthesis of bone-specific collagen [19]. 


\section{Materials and methods}

\section{Materials}

Porcine insulin was obtained from Lilly Co, IGF-I from Bachem and bovine growth hormone from Wilhelmi. Vanadium (IV) oxide sulfate (vanadyl sulfate) was obtained from Merck, catalase and p-nitrophenylphosphate (pNPP) were obtained from SIGMA. Tissue culture materials were provided by Corning or Falcon. Dulbecco's modified Eagle's medium (DMEM), trypsin, ethylenediamine-tetraacetic acid (EDTA) were supplied by GIBCO and fetal bovine serum (FBS) by Gen (Argentina). All other chemicals were of analytical grade from SIGMA. Solutions of vanadate, vanadyl and peroxoderivates were prepared as previously reported [18]. In brief, pervanadate was obtained by reaction of orthovanadate with $\mathrm{H}_{2} \mathrm{O}_{2}$ at $22^{\circ} \mathrm{C}$ for $15 \mathrm{~min}$. The excess of $\mathrm{H}_{2} \mathrm{O}_{2}$ was removed with catalase.

\section{Cell culture}

Rat osteosarcoma cell line UMR106 was grown in DMEM supplemented with $10 \%$ FBS and antibiotics in a humidified atmosphere of $95 \%$ air $/ 5 \% \mathrm{CO}_{2}$. Cells were grown at nearconfluence (70-80\%) and they were subcultured using $0.1 \%$ trypsin- $1 \mathrm{mM}$ EDTA in $\mathrm{Ca}^{2+}-\mathrm{Mg}^{2+}$-free phosphate-buffered saline (PBS). For experiments, about $2.5 .10^{4}$ cells $/ \mathrm{ml}$ were plated into 24 well/plates. After the culture reached $70 \%$ confluence, the cells were washed with DMEM without serum and incubated in $0.5 \mathrm{ml}$ DMEM plus various concentrations of hormones or different vanadium compounds for $24 \mathrm{~h}$.

\section{Cell proliferation assay}

A mitogenic bioassay was carried out as described by Okajima et al. [20] with some modifications. Briefly, cells in 24 well/plate were washed with PBS and fixed with 5\% glutaraldehyde/PBS at room temperature for $10 \mathrm{~min}$. Cells were then stained with $0.5 \%$ crystal violet $/ 25 \%$ methanol for $10 \mathrm{~min}$. After that, the dye solution was discarded and the plate was washed with water and dried. The dye in the cells was extracted using $0.5 \mathrm{ml} /$ well $0.1 \mathrm{M}$ glycine/ $\mathrm{HCl}$ buffer, $\mathrm{pH}$ $3.0 / 30 \%$ methanol and transfered to test tubes. Absorbance was read at $540 \mathrm{~nm}$ after a convenient sample dilution. In order to confirm that the colorimetric bioassay correlated with cell proliferation, the relationship between cell number/well and the absorbance at $540 \mathrm{~nm}$ of diluted extraction sample after crystal violet staining of a different set of wells was examined. Cell number was determined by trypsinization of

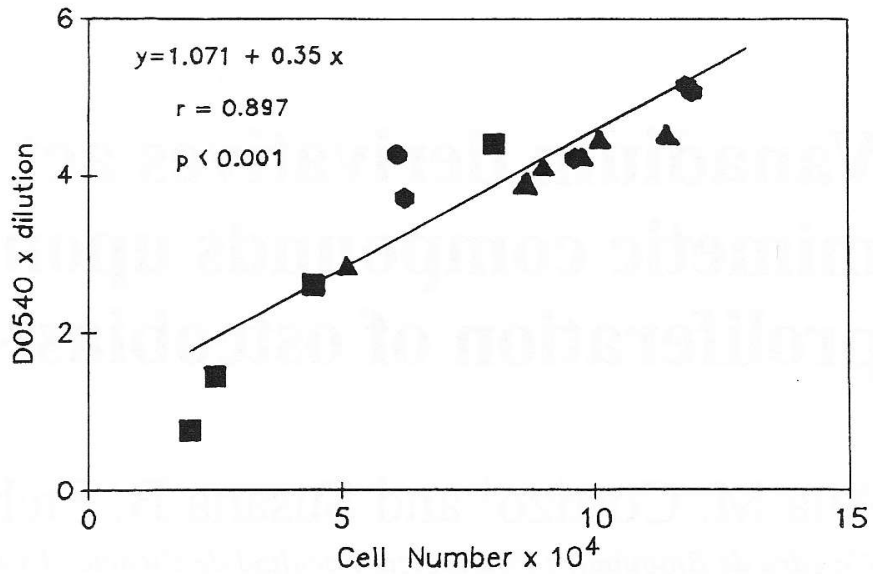

Fig. 1. Correlation between the total cell number per well and the optical density at $540 \mathrm{~nm}$ corrected by dilution of cell extract (crystal violet assay). $\mathbf{\Delta}$ values represent three independent experiments performed by triplicate.

wells and counting with a Neubauer chamber. Figure 1 demonstrates a strong linear correlation between the total cell number/well and OD540 corrected by sample dilution over the range of cell numbers obtained by stimulation with different agents.

\section{Alkaline phosphatase activity}

Cells were incubated at $37^{\circ} \mathrm{C} / 24 \mathrm{~h}$ in a serum-free medium containing different agents. The cell layer was washed with PBS and solubilized in $0.5 \mathrm{ml} 0.1 \%$ Triton-X100. Aliquots of the total cell extract $(10 \%)$ were used for protein determination using the Bio Rad Bradford technique [21] and $10-20 \%$ for measurement of alkaline phosphatase activity. The enzyme activity was assayed by the hydrolisis of pNPP to $\mathrm{pNP}$ at $37^{\circ} \mathrm{C}$ for $15 \mathrm{~min}$ in $20 \mathrm{mM}$ HEPES buffer $\mathrm{pH} 8.0$ in the presence of $20 \mathrm{mM} \mathrm{KCl}$ and $30 \mathrm{mM} \mathrm{MgCl}$. The absorbance at $405 \mathrm{~nm}$ was measured as previously described [18]. Alkaline phosphatase activity is known as a marker of mature osteoblast phenotype and this method has been extensively used to assess cell differentiation in cell culture systems [22-25].

\section{Statistical methods}

Data are expressed as the mean \pm SEM. Statistical differences were analyzed using Student's $t$-test or analysis of variance when suitable. Linear regression analysis was performed by the Pearson's correlation coefficient. 
Table 1. Effect of growth factors on the proliferation and differentiation of UMR 106 cells

\begin{tabular}{llc}
\hline Addition & Proliferation & Differentiation \\
\hline None & $100 \pm 3.3$ & $100 \pm 6.1$ \\
$0.58 \mu \mathrm{g} / \mathrm{ml}$ Insulin & $140 \pm 2.4 \#$ & $59 \pm 1.5^{*}$ \\
$0.75 \mu \mathrm{g} / \mathrm{ml} \mathrm{IGF}-\mathrm{I}$ & $131 \pm 2.1^{*}$ & $54 \pm 3.0^{*}$ \\
$1.0 \mu \mathrm{g} / \mathrm{ml} \mathrm{bGH}$ & $133 \pm 3.2^{*}$ & $84 \pm 3.5$ \\
\hline
\end{tabular}

Cells were exposed to DMEM plus different growth factors for $24 \mathrm{~h}$. Cell proliferation was measured by the crystal violet bioassay and the cell differentiation as alkaline phosphatase activity. Results are expressed as \% over basal (non addition), mean $\pm \operatorname{SEM}(n=4)$. $p$ values vs basal: ${ }^{*} \mathrm{p}<$ $0.01, \# \mathrm{p}<0.001$.

\section{Results}

The addition of insulin, IGF-I and bovine GH to UMR106 cells in serum-free media produced a significant increase in cell proliferation after $24 \mathrm{~h}$ of incubation. The same hormonal doses inhibited cellular differentiation measured through alkaline phosphatase activity (Table 1). Insulin and IGF-I seem to have a similar quantitative effect, while bGH showed a weak effect under comparative conditions. These results showed that the growth of osteoblast-like UMR106 cells is regulated by different hormones and growth factors.

To determine if the UMR 106 cells were also modulated by

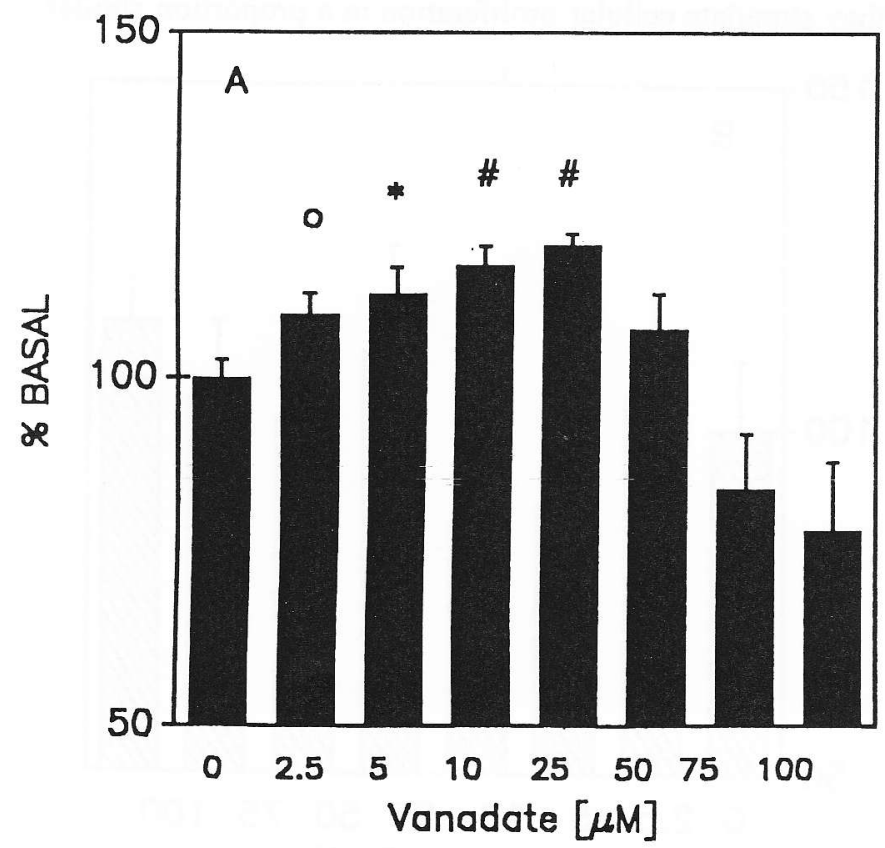

vanadium compounds acting as growth factors, we evaluated the effects of vanadate on cellular proliferation and differentiation. Vanadate stimulated cell proliferation in a biphasic curve manner, with a maximum obtained at 10-25 $\mu \mathrm{M}$, but without further effects (Fig. 2A). High concentrations of vanadate induced a small decrease in cell proliferation.

The action of vanadate upon cell differentiation is shown in a mirror curve with respect to the proliferative effect (Fig. 2B). Maximal inhibition was observed at 5-25 $\mu \mathrm{M}$ and stimulation was seen at 75-100 $\mu \mathrm{M}$. We have previously shown that vanadate, vanadyl and pervanadate $(5-100 \mu \mathrm{M})$ directly inhibit the osteoblast-like cell alkaline phosphatase activity [18]. Accordingly, the results in Fig. 2B could be explained by a direct inhibition of vanadate on alkaline phosphatase. In order to test this hypothesis, in a new series of experiments, the assay was performed in the presence of $25 \mu \mathrm{M}$ EDTA (Table 2$)$. This reagent strongly complexes vanadate $(\mathrm{Ka}=$ $\left.10^{15},[26]\right)$ which otherwise, could be free in the cell extract to inhibit alkaline phosphatase. In the presence of EDTA, the inhibitory effect of vanadate on cell differentiation was reproduced. These results suggest that the effect of vanadate on cell diferentiation, as assessed by alkaline phosphatase activity, was not a direct in vitro inhibitory effect of vanadate but probably a change in the enzyme content.

Since some cellular types are able to reduce vanadate to vanadyl, which seems to be the effective mediator, we tested the effects of vanadyl cation on the UMR 106 cells. Fig. 3A

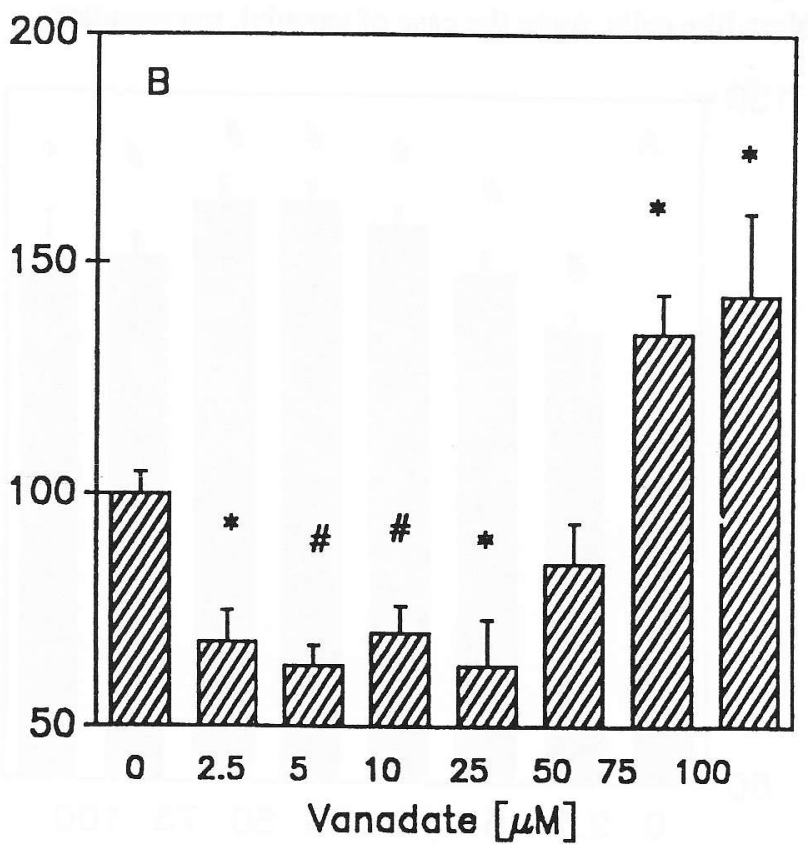

Fig. 2. Effect of vanadate on the cell proliferation and differentiation in osteoblast-like UMR 106 cells. Cells were incubated in DMEM plus vanadate at the doses indicated. After $24 \mathrm{~h}$, cells were washed, fixed and stained with crystal violet to evaluate cell proliferation (A) or solubilized in $0.1 \%$ Triton $\mathrm{X} 100$ to determine alkaline phosphatase activity (B). Data are expressed as $\%$ over basal and indicate the mean \pm SEM $(\mathrm{n}=9$ ). $\mathrm{p}$ values vs basal: $\mathrm{o} p<$ $0.05,{ }^{*} \mathrm{p}<0.02, \# p<0.001$. 
Table 2. Effect of EDTA addition in the alkaline phosphatase assay from UMR 106 cells incubated with vanadate

\begin{tabular}{lcc}
\hline \multirow{2}{*}{$\begin{array}{l}\text { Vanadate } \\
{[\mu \mathrm{M}]}\end{array}$} & ALP activity [\% Basal] \\
\cline { 2 - 3 } & - EDTA & + EDTA \\
\hline 0 & $100 \pm 5$ & $100 \pm 10$ \\
5 & $68 \pm 4 \# \#$ & $71 \pm 5^{*}$ \\
10 & $74 \pm 6 \#$ & $67 \pm 4^{* *}$ \\
25 & $75 \pm 3^{*}$ & $79 \pm 3^{*}$ \\
50 & $92 \pm 8$ & $85 \pm 4$ \\
\hline
\end{tabular}

Cells were incubated in DMEM plus different concentrations of vanadate at $37^{\circ} \mathrm{C} / 24 \mathrm{~h}$. Alkaline phosphatase (ALP) in the cell extract was assayed in the absence or presence of $25 \mu \mathrm{M}$ EDTA: basal activities were $273 \pm 14$ and $306 \pm 32 \mathrm{nmol} \mathrm{pNP/min.mg} \mathrm{protein,} \mathrm{respectively.} \mathrm{Results} \mathrm{are} \mathrm{expressed}$ as $\%$ over basal, mean $\pm \operatorname{SEM}(n=6)$. $p$ values vs their respective basal were: ${ }^{*} p<0.05 ;{ }^{* *} p<0.02 ; \# p<0.002 ; \# p<0.001$. Differences found between the assay in the presence and in the absence of EDTA, were not significant.

shows that vanadyl stimulated cell proliferation at all the used concentrations and did not inhibit cell growth under these conditions. On the other hand, vanadyl had no statistically significant effect upon cell differentiation as can be seen in the results of the alkaline phosphatase activity assay (Fig. 3B).

Pervanadate has been proved to be a more potent insulinmimetic agent $[17,27]$. Fig. $4 \mathrm{~A}$ shows a dose-responsive effect of this vanadium derivative. Similar to vanadate action, pervanadate statistically increased cell proliferation at 5-25 $\mu \mathrm{M}$. Higher concentrations did not affect the growth of the osteoblast-like cells. As in the case of vanadyl, pervanadate

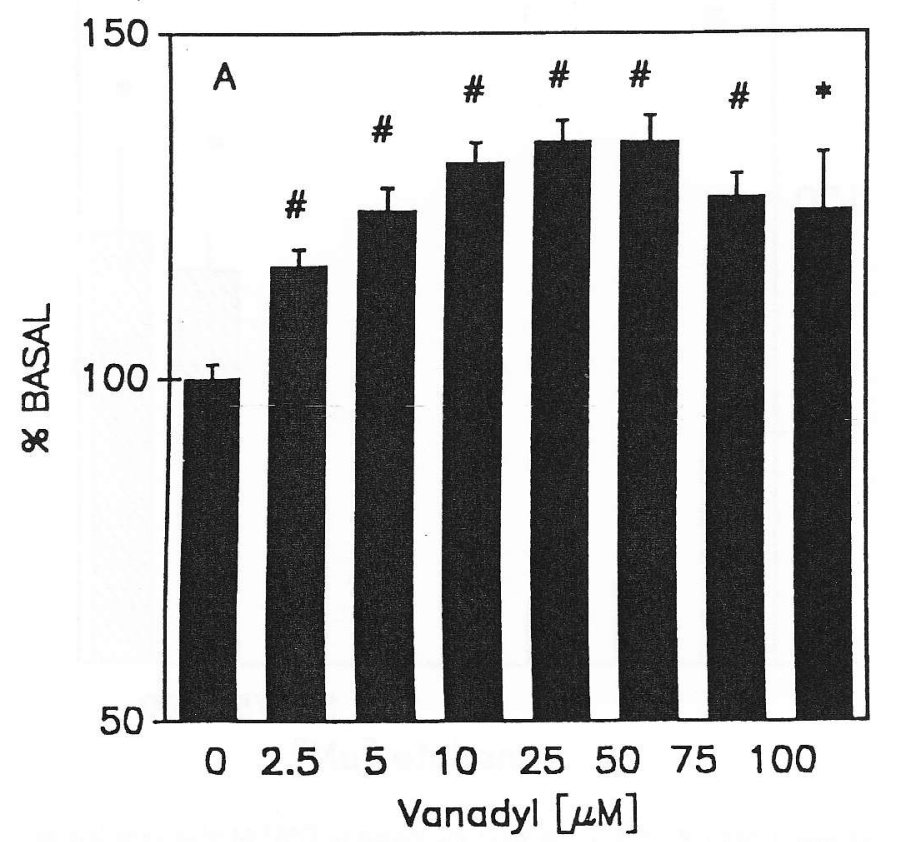

had no action on cell differentiation (Fig. 4B) as assayed by alkaline phosphatase activity. These results are in contrast with the direct effect of pervanadate previously observed in the fraction of UMR 106 cells [18].

The effectiveness of the three vanadium derivatives at maximum dose was compared. Vanadyl $(25 \mu \mathrm{M})$ and pervanadate $(25 \mu \mathrm{M})$, which showed the maximum stimulation in cell proliferation, were $134 \pm 3$ and $135 \pm 4 \%$ above basal, respectively, whereas vanadate $(25 \mu \mathrm{M})$ increased osteoblast-like cell growth by $119 \pm 2 \%$ over basal $(p<0.001)$. These results show that vanadyl and pervanadate are stronger stimulators than vanadate.

\section{Discussion}

The present study was undertaken to examine the effects of different vanadium compounds on osteoblast-like cell proliferation and differentiation in vitro. Vanadate increases cell growth in a biphasic manner. This pattern has been previously shown by Canalis in culture rat calvaria [11], Kato et al in rabbit costal chondrocyte culture [12] and Davidai et al in MC3T3-E1 cells [16]. In all the cases, the higher concentrations tested clearly inhibited cell proliferation. Vanadyl and pervanadate seemed to be better mitogens since they did not inhibit cell growth in osteoblast-like UMR 106 cells and also showed a more potent effect than vanadate.

These vanadium compounds behave like growth factors: they stimulate cellular proliferation in a proportion similar

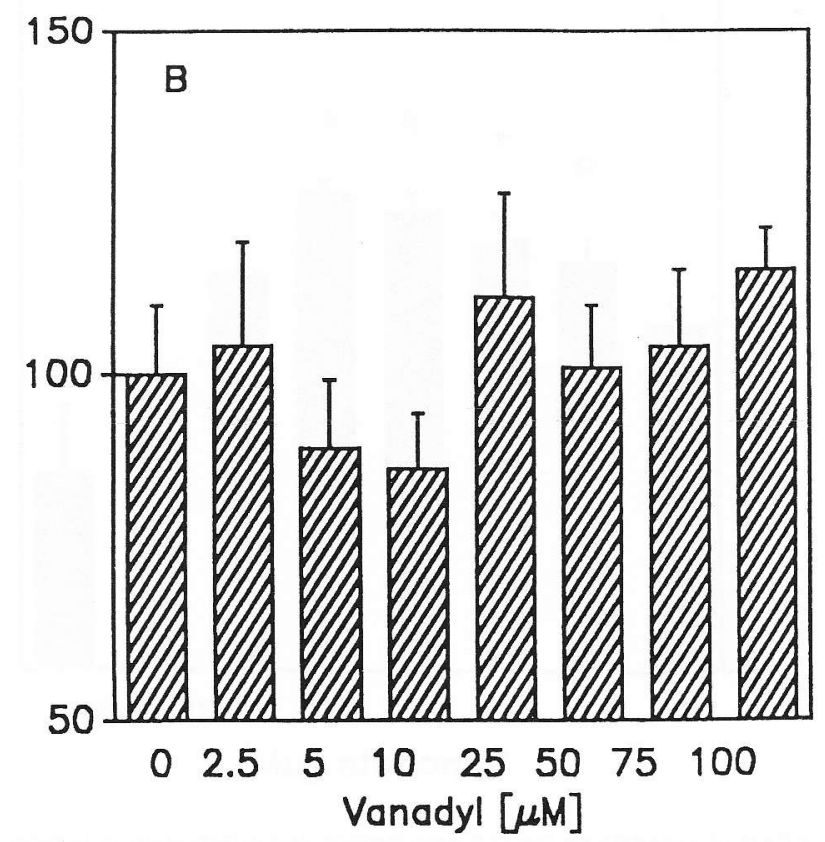

Fig. 3. Effect of vanadyl on cell proliferation (A) and differentiation (B) in osteoblast-like UMR106 cells. Data are expressed as \% over basal and indicate the mean $\pm \operatorname{SEM}(n=9)$. $p$ values vs basal: ${ }^{*} p<0.02, \# p<0.001$. 

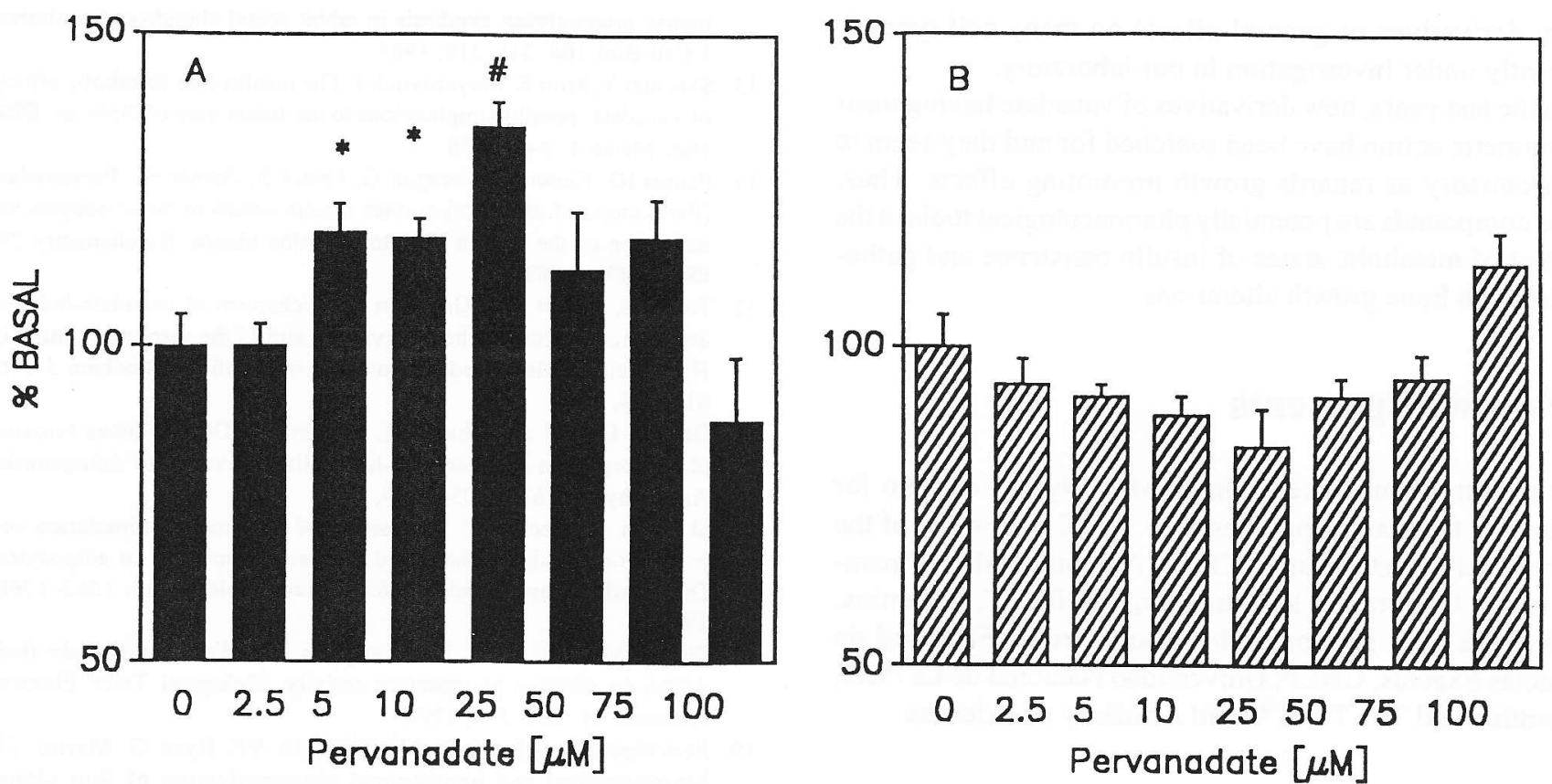

Fig. 4. Effect of pervanadate on cell proliferation (A) and differentiation (B) in osteoblast-like UMR106 cells. Data are expressed as \% over basal and indicate the mean $\pm \operatorname{SEM}(n=9)$. $p$ values vs basal: ${ }^{*} p<0.02, \# p<0.001$.

to insulin and IGF-I (Table 1). The UMR106 cells possess binding sites for insulin and IGF-I, but at the doses used for insulin, the latter probably stimulates cell proliferation through Type-1 IGF receptor (unpublished observations). These receptors became phosphorylated upon binding the cognate hormone [28]. Since vanadate has been postulated to specifically inhibit PTPases, it could regulate cell growth by enhancing insulin or IGF autophosphorylation. In adipose tissue it has been shown that vanadate stimulates glucose metabolism by a mechanism other than autophosphorylation of the insulin receptor [17]. Thus, vanadate could not produce additional activation of insulin effects in those cells. On the other hand, pervanadate was able to potentiate the hormone effect in adipocytes by increasing the autophosphorylation of insulin receptors [17]. We have previously shown [18] that UMR 106 cells have a cytosolic alkaline phosphatase, partially characterized as a PTPase. This enzyme was directly inhibited in the in vitro assay by vanadium derivatives. Thus, the inhibition of a specific PTPase is likely to play a role in the modulation of UMR 106 cell growth.

Pervanadate and vanadyl seem to be less important in the control of cell differentiation, as has been demonstrated by the ALP assay. It is known that pervanadate is unstable and spontaneously decomposes to vanadate [27]. Although we did not test this process during our cell incubation period, the absence of pervanadate effect on cell differentiation (Fig. 4B) suggests that not enough vanadate was generated to inhibit cell differentiation (it has to be at least $\geq 2.5 \mu \mathrm{M}$, Fig. $2 \mathrm{~B}$ ). On the other hand, we have previously shown [18] that both vanadyl and pervanadate directly inhibit a partially characterized citosolic PTPase in UMR 106 cells. Thus, this mechanism, although not directly tested by the authors, would partially explain the vanadium compound stimulatory effect on cell proliferation. Vanadate was the only compound which inhibited cell differentiation at mitogenic doses. This effect was not a direct in vitro inhibition of alkaline phosphatase activity but rather a decrease in the enzyme amount. Considering that the cell monolayer was resuspended in $0.5 \mathrm{ml}$ solubilization solution, a rough estimate of vanadate concentration in the extract suggests that it should be diluted to the extent that it does not directly affect the alkaline phosphatase activity. The experiment performed in the presence of EDTA, in a concentration estimated to totally complex free vanadate [26] did not blunt out the vanadium effect on cell differentiation. A similar effect, induced by insulin, was observed in Ros 17/2.8 rat osteosarcoma cells [7]. However, Canalis et al. found that treatment with vanadate did not stimulate ALP activity in a calvaria culture [11]. This enzyme was inhibited in bone exposed to $1 \mathrm{mM}$ vanadate, a dose which caused inhibition of thymidine incorporation into DNA. In our study the higher doses of vanadate $(\geq 75 \mu \mathrm{M})$ activated alkaline phosphatase, an effect not observed in the presence of other vanadium derivatives. This could be a compensatory effect of osteoblast-like cells, under a condition of decreased cell proliferation [22]. Those studies and the present one suggest that pervanadate as well as vanadyl can regulate cell proliferation without the cell growth inhibitory effect observed with vanadate. Whether these are tissue-specific effects of vana- 
dium derivatives or general effects on many cell types is currently under investigation in our laboratory.

In the last years, new derivatives of vanadate having insulin-mimetic action have been searched for and they seem to be promisory as regards growth promoting effects. Thus, these compounds are potentially pharmacological tools in the control of metabolic states of insulin resistence and pathologies with bone growth alterations.

\section{Acknowledgements}

The authors would like to thank Miss Nyria Fenoglio for reviewing the manuscript language. $A M C$ is member of the Carrera del Investigador, CICPBA, Argentina; SBE is member of the Carrera del Investigador, CONICET, Argentina. This work was supported by grants from: Facultad de Ciencias Exactas, UNLP; Universidad Nacional de La Plata, Argentina and The Third World Academy of Sciences.

\section{References}

1. Compston JE: Osteoporosis. Clin Endocrinol 33: 653-682, 1990

2. Marcus R: Skeletal aging. Understanding the functional and structural bases of osteoporosis. Trends Endocrinol Metab 2: 53-58, 1991

3. Cooper C, Melton J II: Epidemiology of osteoporosis. Trends Endocrinol Metab. 3: 224-229, 1992

4. Farley JR, Tarbaux N, Murphy LA, Masuda T, Baylink DJ: In vitro evidence that bone formation may be coupled to bone resorption by release of mitogen(s) from resorbing bone. Metabolism 36: 314-321, 1987

5. Baylink DJ, Finkelman RD, Mohan S: Growth factors to stimulate bone formation. J Bone Min Res 8, Supp 2: S565-S572, 1993

6. Centrella $\mathrm{M}$, Canalis $\mathrm{E}$ : Local regulators of skeletal growth: a perspective. Endocr Rev 6: 544-551, 1985

7. Levy JR, Murray E, Manolagas S, Olefky JM: Demonstration of insulin receptors and modulation of alkaline phosphatase activity by insulin in rat osteoblastic cells. Endocrinology 119: 1786-1792, 1986

8. Mohan S, Baylink DJ: The role of insulin-like growth factor-II in the coupling of bone formation to resorption. In: E.M. Spencer (ed.). Modern Concepts in Insulin-like Growth Factors. Elsevier, New York, 1991, pp. 169-184

9. Hashizume M, Yamaguchi M: Stimulatory effect of $\beta$-alanyl-Lhistidinato zinc on cell proliferation is dependent on protein synthesis in osteoblastic MC3T3-El cells. Mol Cell Biochem 122: 59-64, 1993

10. Nielsen FH, Uthus EC: The essentiality and metabolism of vanadium.In: N.D. Chasteen (ed.). Vanadium in Biological Systems. Kluwer Academic Publishers, Netherlands, 1990, pp. 51-62

11. Canalis $\mathrm{E}$ : Effect of sodium vanadate on deoxyribonucleic acid and protein synthesis in cultured rat calvariae. Endocrinology 116 : 855-862, 1985

12. Kato Y, Iwamoto M, Koke T, Suzuki F: Effect of vanadate on cartilage- matrix proteoglycan synthesis in rabbit costal chondrocyte cultures. J Cell Biol 104: 311-319, 1987

13. Shechter Y, Amir S, Meyerovitch J: The insulin-like metabolic effects of vanadate: possible implications to the future care of diabetes. Diab Nutr Metab 1: 1-5, 1988

14. Fantus IG, Kadota S, Deragon G, Foster B, Posner BI: Pervanadate [Peroxide(s) of vanadate] mimics insulin action in rat adipocytes via activation of the insulin receptor tyrosine kinase. Biochemistry 28 : $8864-8871,1989$

15. Trudel S, Paquet MR, Grinstein S: Mechanism of vanadate-induced activation of tyrosine phosphorylation and of the respiratory burst in HL60 cells. Role of reduced oxygen metabolites. Biochem J 276: $611-619,1991$

16. Davidai G, Lee A, Schuartz I, Hazum E: PDGF induces tyrosine phosphorylation in osteoblast-like cells: relevance to mitogenesis. Am J Physiol 263: E205-E209, 1992

17. Shisheva A, Shechter Y: Mechanism of pervanadate stimulation and potentiation of insulin-activated glucose transport in rat adipocytes. Dissociation from vanadate effect. Endocrinology 133: 1562-1568, 1993

18. Cortizo AM, Salice VC, Etcheverry SB: Vanadium compounds: their action on alkaline phosphatase activity. Biological Trace Element Research 41: 331-339, 1994

19. Partridge NC, Alcorn D, Michelangeli VP, Ryan G, Martin TJ: Morphological and biochemical characterization of four clonal osteogenic sarcoma cell lines of rat origin. Cancer Res 43: 4308-4314, 1983

20. Okajima $T$, Nakamura $K$, Zhang $H$, Ling $N$, Tanabe $T$, Yasuda $T$, Rosenfeld RG: Sensitive colorimetric bioassays for insulin-like growth factor (IGF) stimulation of cell proliferation and glucose consumption: use in studies of IGF analogs. Endocrinology 130: 2201-2212, 1992

21. Bradford M: Rapid and sensitive method for quantitation of microgram quantities of protein utilizing the principle of proteindye binding. Anal Biochem 72: 248-254, 1976

22. Stein GS, Lian JB: Molecular mechanism mediating proliferation/ differentiation interrelationships during progressive development of the osteoblast phenotype. Endocrine Rev 14: 424 442, 1993

23. Schmid $\mathrm{CH}$, Steiner TH, Froesch ER: Insulin-like growth factors stimulate synthesis of nucleic acids and glycogen in cultured calvaria cells. Calcif Tissue Int 35: 578-585, 1983

24. Bonewald LF, Schwartz Z, Swain LD, Ramirez V, Poser J, Boyan $B D$ : Stimulation of plasma membrane and matrix vesicle enzyme activity by transforming growth factor- $\beta$ in osteosarcoma cell cultures. J Cell Physiol 145: 200-206, 1990

25. Zhang RW, Simmons DJ, Crowther RS, Mohan S, Baylink DJ: Contribution of marrow stroma cells to the regulation of osteoblast proliferation in rats: evidence for the involvement of insulin-like growth-factors. Bone and Mineral 13: 201-215, 1991

26. Crans DC, Bunch RL, Theisen LA: Interaction of trace levels of vanadium (IV) and vanadium (V) in biological systems. J Am Chem Soc 111: 7597-7607, 1989

27. Kadota S, Fantus IG, Deragon G, Guyda HJ, Hersh B, Posner BI: Peroxide(s) of vanadium: a novel and potent insulin-mimetic agent which activates the insulin receptor kinases. Biochem Biophys Res Comm 147: 259-263, 1987

28. Yarden Y, Ullrich A: Growth factor receptor tyrosine kinases. Ann Rev Biochem 57: 443-478, 1988 